\title{
An Assessment of IT Outsourcing Practices in the North-West Provincial Government: South Africa
}

\author{
Nehemiah Mavetera \\ North-West University, Mmabatho, South Africa, \\ Email: nehemiah.mavetera@nwu.ac.za \\ Ntebogang Dinah Moroke \\ North-West University, Mmabatho, South Africa, \\ Email: Ntebo.Moroke@nwu.ac.za \\ Dumisane Mtotoba \\ North-West University, Mmabatho, South Africa, \\ Email:dmtotoba@gmail.com
}

Doi:10.5901/mjss.2014.v5n14p25

Abstract

This study investigated practices that are followed when outsourcing Information Technology (IT) services in the North-West Provincial Government (NWPG) of South Africa. NWPG is a tier two level in the South African government structure and lies in between the national and the local governments. As a departure point, the research study identified the best practices in IT outsourcing, the most important benefits of this process as well as the shortcomings of IT outsourcing. The study is a culmination of requests from the provincial government stakeholders to have a framework of IT outsourcing best practices which is currently not available. The study used quantitative approach and a questionnaire as a research instrument. Findings revealed that the decision to outsource can sometimes be difficult to make and is risky. However, it also identified some benefits of IT outsourcing such as access to highly experienced IT specialists, access to advanced technologies, as well as improvement in customer service quality. Some risks associated with outsourcing such as hidden costs and loss of control on outsourced activities was also revealed. In addition, outsourcing may lead to increased unemployment and may negatively affect employees' morale. It is recommended that NWPG should adopt an outsourcing plan that will guide its outsourcing process as well as establishing a clear understanding of its requirements, performing due diligence as well as carrying out of risk assessment during this process. Efficient and open communication channels between staff and management levels should also be developed.

Keywords: IT Outsourcing, Strategy; Risk, North West Provincial Government, South Africa

\section{Introduction}

The rapid changes in IT industry have not only brought new and improved IT infrastructure to organizations, but also the unenviable headaches of managing and maintaining these IT infrastructures. This problem becomes more difficult in public organizations such a Provincial governments where IT portfolios that comprise of IT staff, hardware, software, network infrastructure and the processes thereof attract very little budget. This has forced governments world over to look at IT outsourcing as an alternative strategy.

This study investigated issues that are faced by NWPG when outsourcing Information Technology Services. Normally managers decide to outsource IT services for several reasons ranging from operational, technological through to financial benefits that can be derived from such an endeavour.

According to Kermis (2006), outsourcing is a common practice among both private and public organisations and is a major element in modern business strategy formulation. The strategic aim of outsourcing for government is to improve service delivery and reduce cost by making significant changes which are deemed not possible in the current public services environment. It may also be used as a solution to gain management expertise that is not available from within. Outsourcing of government services to private service providers is not a new phenomenon. According to Matthews (2007:1): 
'the history of outsourcing can be traced back in time to the natural evolution of specialization of skills and the use of captured resources to perform labor intensive work. IT Outsourcing (ITO) obviously falls in the highly skilled category and has been growing rapidly since taking root in the 1970s. Today's telecommunications advances, the internet's ubiquity and availability of global technology resources have made ITO a huge worldwide business.'

Putting this into context, this study investigated the NWPG's outsourcing practices. These practices are viewed in relation to the role played by the South African State Information Technology Agency (SITA), which was established to manage, consolidate and coordinate the South African State's information technology resources in order to achieve cost savings through economies of scale, increased delivery capabilities and enhanced inter-operabilities (SITA 2008). The rest of the paper is as follows: The problem statement is discussed first followed by a brief presentation of the extant literature on ITO. The research methodology is then followed by a presentation of the results. The paper concludes with a reflection on practices in ITO.

\section{Problem Statement}

During his 2010/11 budget speech, the NWPG Member of Executive Council (MEC) for the Treasury Department, Mabe (2010:21) mentioned that:

'As Provincial Treasury, in doing ICT business we have to comply with legislation by signing Service Level Agreement (SLA) or Business Agreement (BA) with SITA as stipulated by the SITA act. We will finalise the decentralisation process of its functions during this year but also improve our working relations with SITA.'

This statement confirms the obligations and the mandatory nature of the IT outsourcing process by the NWPG. However, this creates a concern among IT staff and other provincial departments relying on IT to provide services. According to Gonzalez et al (2009), outsourcing causes staff problems as workers face an uncertain situation that provokes anxiety, low morale and a feeling of insecurity, which can lead to a decrease in their productivity levels. Quite often, the outsourcing decision is not communicated to staff, and it is not clear nor known what services or tasks are to be outsourced, what the structure of the service level agreement with SITA will be and how this will impact on the staff. While the NWPG MEC for Finance, under which the department of IT services falls, made the mandatory ITO proclamation, he did not however address the specific aspects of this outsourcing strategy. This lack of a clear strategic focus raised serious concerns amongst IT staff and the departments that are serviced by this IT department. It is on this note that this study was initiated. As its departure point, the research proposed that developing a clear and sound outsourcing strategy will significantly produce positive outsourcing outcomes rather than just compliance with legislation. The next section discusses the extant literature on ITO.

\section{Related Literature}

According to Cox et al. (2011), companies may outsource their core value-chain operations or their support activities. In addition, ITO is becoming popular because of new emerging trends such as unified communications, managed services, cloud computing (i.e. hosted data centers) and enterprise mobile applications (Sun 2011). In addition, several IT governance frameworks and standards have been proposed and used such as COBIT, ITIL, Prince 2 to mention but a few that come with competency requirements IT departments may not possess. In also keeping up with the high service demands of organizations, several service strategies have also been adopted such as Software as a Service (SaaS), Platform as a Service (PaaS) Network as a Service Naas) and many more. All these have added a compelling requirement to organizations to consider outsourcing as a service strategy that can increase the quality of their IT services.

Smuts et al. (2010), Haag et al. (2007) and Cox et al. (2011)) all contend that outsourcing entails the act of transferring work, responsibilities and decision rights to someone else. This is usually an external third party. It is the practice of hiring functional experts to handle business units that are outside the firm's core business, which in turn enhances the organization's service delivery. This process augments staff without adding to the head count (Dominguez 2006). In recent years, more and more companies have decided to outsource partially or totally, their IT services. Smuts et al (2010) identified three sourcing decisions that can be made. These are:

- Total outsourcing - the decision to transfer IT assets, leases, staff and management responsibility for delivery of IT products and services from an internal IT function to a third party vendor which represents more than 
$80 \%$ of the IT budget.

- Total insourcing - the decision to retain the management and provision of more than $80 \%$ of the IT budget internally after evaluating the IS budget and lastly,

- Selective sourcing - the decision to source selected IT functions from one or more external providers while still providing between $20 \%$ and $80 \%$ of the IS budget internally.

The outsourcing strategy that is used by an organization can be dictated upon by several factors that range from political, financial or organizational culture. Brandas (2010) notes that recently, there has been a significant move towards selective outsourcing. Some key elements to outsourcing include:

- Cost, quality and efficiency.

- Contracting out or selling the organization's IT assets, people and/or activities.

- 3rd party supplier and service level agreements and

- Access to skilled, experienced and well-trained professionals.

Nevertheless, the outsourcing process exposes both clients and service providers to a series of risks that can seriously affect their activities if not managed properly. In order for a company's IT outsourcing strategy to succeed, adherence to best practices is critical.

\subsection{Organizational Reasons to Outsource}

According to Dominguez et al. (2006), the reasons forcing a move to outsourcing are but not limited to: fast advancements in technology, sophistication of business operations and the need for constant growth. Also, organizations are forced to focus on core competencies. McMillan and Shukla (2010) noted that the decision to outsource is usually made at senior levels of corporate management. Kremic and Tukel (2006) urge outsourcing organizations to ensure serious sufficient planning, intrinsic communication and enough human resources. Also, a transition plan must be drawn up, indicating which services will be transferred and over what period of time.

To develop a strategic sourcing plan, senior management should agree on the methodology and approach, including measuring critical success factors. According to Remenyi et al. (2007), outsourcing may not always lead to cost reductions as is always touted and can at times be very risky.

\subsubsection{Financial Aspect}

Usually outsourcing is regarded as a means of achieving substantial cost savings quickly. It is important to do a financial assessment to determine the actual cost of outsourcing. The financial situation of the NWPG is that IT is considered as a fixed cost, while all the other provincial departments perceive the IT services as free of charge. Hence the NWPG's outsourcing plan might modify these perceptions and might generate some discipline in the IT system evaluation.

\subsubsection{The Human Factor}

Jones (2009) states that ignoring the people side of outsourcing is the first blunder. It is probably the most deadly mistake and directly shows a lack of concern for people. All the people in the organisation are affected by outsourcing, that is, the managers, the clients, the leaders responsible, the people transferred, the people retained, as well as the people retrenched.

Communication and timing are vitally important, in both the announcement and the management of the transition. Jones (2009) further states that human factors are the most important and among the most difficult issues during an outsourcing process. The best and most experienced employees may take their knowledge and skills to another employer. Another group may feel inadequate or afraid of change and oppose outsourcing at every opportunity. The impact on the people being outsourced is frequently one of frustration. As a result, organizations are encouraged to employ suitable change management strategies for this process to succeed.

\subsection{Some IT Outsourcing Risks}

The risks related to IT outsourcing can range from failure to align outsourcing strategy with corporate objectives, servicelevel agreements not being implemented, operational, human resources (HR), and regulatory implications not being considered and failure to plan for contingency arrangements. Arshad et al. (2007) state that one of the major risks of IT 
outsourcing is the assurance that the outsourced personnel possess adequate knowledge regarding the related technologies used in the IT outsourcing projects. More importantly, ITO, more often than not, neglects the cultural setting of the organization.

This is supported by Deloitte.com website (http://deloitte.wsj.com), which cites serious risks facing IT outsourcing as the operational and transactional risk, understanding all business process flows, risks to the confidentiality of information, including security and data controls, and lastly, risks to business continuity and compliance risk. Many of the outsourcing problems find their roots in the original drivers of ITO that are not well aligned with the original context.

\subsection{IT Outsourcing in NWPG}

North-West Provincial IT Directorate is responsible for Transversal Services which include the WAN, CAN, LAN, Telephony and Financial Systems. It comprises three (3) sub directorates namely, E-Government Services, Information Technology Services and Business Software Services.

According to Mabe (2010), the department has struggled for the past nine years to finalise the migration of its IT services to SITA. The concern is that, the provincial government does not cite the obstacles that hinder them to finalise their IT outsourcing process. However, at its 2009 strategic planning session, the North-West Provincial IT department outlined the following as challenges facing the IT directorate:

- Having the right mixture of IT skills and competencies

- Lack of IT Governance Structures

- $\quad$ Non-apparent transparent IT investment processes in NWPG

- Longer lead times between IT adoption and IT policy formulation.

- Articulating customer demand (society, business and government)

- The role of Chief Financial Officers and Treasury in the Provincial and Departmental IT investment process (current IT maturity: cost-justifiable IT investments - the ratification of IT investment done somewhere else).

- IT's Extended Mandate that is, should departments be responsible for their own demand and supply and finally,

- Corporate culture which is the contextual mix of NWPG as an organization.

Brandas (2010) notes that when the IT department effectiveness and efficiency are lacking, and the department is not working properly they may be forced to outsource this function to an external provider. However, ADP (2005) warns that outsourcing should not be imagined to be a panacea solution to all perceived IT problems. It is not a relatively straightforward transaction involving the simple transfer of services to a supplier, but it matters mostly on how the strategy is planned, implemented, and managed (Willcocks, et al. 2011).

\subsection{SITA as the South African Government's Outsourcing Agency}

As stated earlier, SITA is governed by the SITA Act No. 88 of 1998, to consolidate and coordinate the State's information technology resources (http://www.sita.co.za/). Furthermore, the Act separates SITA's services into mandatory services (i.e. services that SITA must provide), and non-mandatory services (i.e. services that SITA may provide). It is because of this act that the MEC in the department of Finance decided to outsource IT services to SITA. However, no one has done a research to find out the performance of SITA with regard to IT outsourcing.

SITA has suffered negative reporting from the print media. In addition, the South African minister in the department of Public Service and Administration has also acknowledged SITA's poor performance. According to Rasool (2011), SITA was established to ensure that government would benefit through bulk purchasing of ICT goods and services and to deliver e-government services as well as establish an ICT skills development plan.

However, it has been beleaguered by allegations of large-scale corruption, irregular procurement practices, and poor governance and leadership. It has also been plagued by a lack of top-level stability as several permanent and acting Chief executive officers (CEO) have come and gone since the agency's inception. This brief discussion on the NWPG IT department and SITA's role was used in conjunction with other sources cited herein to develop the research instrument used for the study.

\section{Research Methodology}

The research study used a quantitative research approach. According to Struwig and Stead (2011), quantitative research 
is a form of conclusive research involving large representative samples and fairly structured data collection procedures. Due to the quantitative nature of the research study a questionnaire was employed to collect the research data. The questionnaire consisted of odd numbered likert scale and checkbox type closed-ended questions in order to simplify the interpretation of the findings and to ensure simplicity and timeliness for participants.

The population for the study was all the employees of NWPG, Department of Finance and IT directorate. The directorate has a population of sixty six (66) employees. This research used random sampling where one selects, entirely at random a sample of the population. Randomly therefore, only fifty three (53) employees participated in the study, which amount to eighty per cent (80\%) of the entire NWPG IT staff. The study's sample distribution is depicted in Table 1.

Table 1: Sample Distribution

\begin{tabular}{|l|c|c|}
\hline \multicolumn{1}{|c|}{ Department of Finance: IT Directorate } & Number of employees per sub unit & Percentage \\
\hline Management & 6 & $11.3 \%$ \\
\hline System Admin/Support & 17 & $32.1 \%$ \\
\hline Information Security & 4 & $7.5 \%$ \\
\hline Development/Programming & 12 & $22.6 \%$ \\
\hline Networking Total & 14 & $26.4 \%$ \\
\hline \multicolumn{2}{|c|}{ T3 } & $100 \%$ \\
\hline
\end{tabular}

\section{Data Analysis and Results}

\section{Demographical Background}

The majority $(75.5 \%)$ of respondents were male, while $24.5 \%$ of the respondents are female. In terms of educational qualifications, the majority (35.8\%) of respondents have a post-matric qualification. Figure 1 shows the distribution of personnel according to their job function.

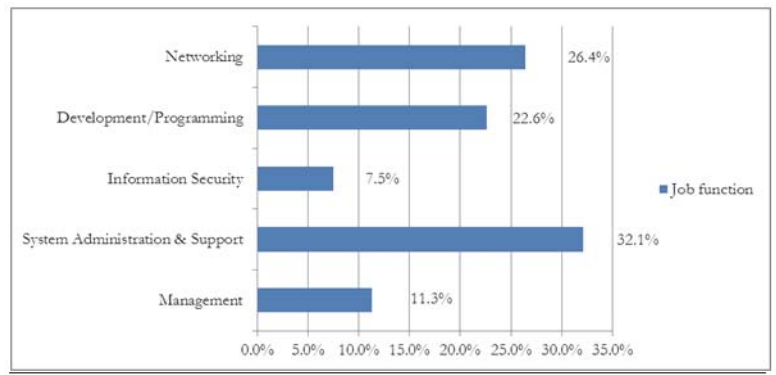

Figure 1: Respondents' Job function

In terms of years of working experience, the majority (60.4\%) of respondents have 11years and above of experience in IT. $18.9 \%$ of respondents have 1 to 3 years of experience, whereas $13.2 \%$ and $7.5 \%$ of the respondents have 7 to 10 and 4 to 6 years of experience respectively.

Table 2 presents the distribution of responses to three knowledge areas of ITO namely:

- Knowledge of ITO issues and processes

- Knowledge of ITO drivers and,

- Knowledge of IT functions and activities.

The comment column in Table 2 gives our reflection on these responses. With regard to these three areas, the study proposed that:

Proposition A:

Participants are knowledgeable of ITO purpose and its processes.

Proposition B:

ITO exposes the organization to more and better facilities and resources that increase its competitive advantage or variety superiority

Proposition C:

ITO does not expose the organization to operational risk. 
Table 2: IT Outsourcing Issues

\begin{tabular}{|c|c|c|c|c|c|c|}
\hline Research Construct & $\begin{array}{l}\text { Strongly } \\
\text { Agree }\end{array}$ & Agree & Neutral & Disagree & $\begin{array}{l}\text { Strongly } \\
\text { Disagree }\end{array}$ & Comment \\
\hline \multicolumn{7}{|c|}{ Knowledge of ITO issues } \\
\hline $\begin{array}{l}\text { Understand IT outsourcing } \\
\text { concept }\end{array}$ & 15.1 & 49.1 & 18.9 & 11.3 & 5.7 & $\begin{array}{l}\text { Majority (64.2\%) of participants understand } \\
\text { what is outsourcing }\end{array}$ \\
\hline $\begin{array}{l}\text { There is a clear ITO Strategy by } \\
\text { NWPG }\end{array}$ & 5.7 & 20.8 & 24.5 & 28.3 & 20.8 & $\begin{array}{l}\text { The ITO strategy is not understood(73.6\%) by } \\
\text { the participants }\end{array}$ \\
\hline $\begin{array}{l}\text { There are efficient and open } \\
\text { communication channels by the } \\
\text { NWPG }\end{array}$ & 1.9 & 5.7 & 18.9 & 35.8 & 37.7 & $\begin{array}{l}\text { Communication is a very big challenge in the } \\
\text { department as only } 7.6 \% \text { agree with this } \\
\text { statement }\end{array}$ \\
\hline $\begin{array}{l}\text { There is a documented } \\
\text { outsourcing plan }\end{array}$ & 3.8 & 7.5 & 18.9 & 35.8 & 34.0 & Only $11.3 \%$ have knowledge of ITO plan. \\
\hline $\begin{array}{l}\text { There is change control process } \\
\text { in place regarding NWPG ITO }\end{array}$ & 0.0 & 11.3 & 22.6 & 32.1 & 34.0 & $\begin{array}{l}\text { 11.3\% have an understanding of ITO change } \\
\text { control processes. This can be attributed to } \\
\text { the fact that only managers and supervisors } \\
\text { are privy this type of information. }\end{array}$ \\
\hline \multicolumn{7}{|c|}{ ITO Drivers } \\
\hline $\begin{array}{l}\text { ITO brings access to best } \\
\text { technology }\end{array}$ & 28.3 & 34.0 & 24.5 & 5.7 & 7.5 & $\begin{array}{l}\text { Majority (62.3\%) agree that ITO avails best } \\
\text { technology }\end{array}$ \\
\hline ITO improves performance & 17.0 & 43.4 & 20.8 & 9.4 & 94.4 & $\begin{array}{l}\text { 60.4\% believe ITO gives an urge to } \\
\text { performance }\end{array}$ \\
\hline $\begin{array}{l}\text { ITO provides access to skilled, } \\
\text { experienced and well trained } \\
\text { professionals }\end{array}$ & 11.3 & 43.4 & 32.1 & 7.5 & 5.7 & $\begin{array}{l}54.7 \% \text { support the notion that ITO increases } \\
\text { the professional pool of resources }\end{array}$ \\
\hline $\begin{array}{l}\text { ITO provides improved service } \\
\text { and quality levels }\end{array}$ & 17.0 & 39.6 & 26.4 & 7.5 & 9.4 & Majority $(56,6 \%)$ support this notion \\
\hline $\begin{array}{l}\text { ITO brings better career } \\
\text { opportunities }\end{array}$ & 18.9 & 26.4 & 22.6 & 24.5 & 7.5 & $\begin{array}{l}\text { This is refuted (54.6\%). ITO is linked to higher } \\
\text { unemployment levels. }\end{array}$ \\
\hline $\begin{array}{l}\text { ITO is a fact of following industrial } \\
\text { trends }\end{array}$ & 17.0 & 41.5 & 26.4 & 9.4 & 5.7 & Majority $58.5 \%$ agree \\
\hline $\begin{array}{l}\text { ITO is a way of complying with } \\
\text { legislation }\end{array}$ & 18.9 & 47.2 & 22.6 & 7.5 & 3.8 & Majority $66.1 \%$ agree \\
\hline $\begin{array}{l}\text { ITO can be used to reduce and } \\
\text { control IT costs }\end{array}$ & 3.8 & 17.0 & 34.0 & 28.3 & 17.0 & Majority $79.3 \%$ disagree \\
\hline \multicolumn{7}{|c|}{ IT functions and activities } \\
\hline $\begin{array}{l}\text { ITO should focus on Mainframes } \\
\text { applications }\end{array}$ & 18.9 & 30.2 & 17.0 & 20.8 & 13.2 & $50.9 \%$ disagree \\
\hline $\begin{array}{l}\text { Application development and } \\
\text { maintenance should be } \\
\text { outsourced }\end{array}$ & 7.5 & 32.1 & 20.8 & 32.1 & 7.5 & $60.4 \%$ disagree \\
\hline $\begin{array}{l}\text { Desktop systems must be } \\
\text { outsourced }\end{array}$ & 9.4 & 22.6 & 22.6 & 32.1 & 13.2 & $67.9 \%$ disagree \\
\hline \begin{tabular}{|l|} 
Networked services must be \\
outsourced
\end{tabular} & 15.1 & 39.6 & 13.2 & 22.6 & 9.4 & $54.7 \%$ agree \\
\hline $\begin{array}{l}\text { Help desk function should be } \\
\text { outsourced }\end{array}$ & 13.2 & 17.0 & 9.4 & 34.0 & 26.4 & $69.8 \%$ disagree \\
\hline $\begin{array}{l}\text { IT security services should be } \\
\text { outsourced }\end{array}$ & 17.0 & 18.9 & 20.8 & 28.3 & 15.1 & $64.2 \%$ disagree \\
\hline $\begin{array}{l}\text { Internet/intranet/email } \\
\text { applications must be outsourced }\end{array}$ & 5.7 & 15.1 & 13.2 & 45.3 & 20.8 & 79.3\% disagree \\
\hline $\begin{array}{l}\text { ITO enhances the performance of } \\
\text { the whole organization }\end{array}$ & 13.2 & 35.8 & 30.2 & 13.2 & 7.5 & $51.0 \%$ disagree \\
\hline $\begin{array}{l}\text { ITO makes organizations more } \\
\text { effective }\end{array}$ & 9.4 & 43.4 & 22.6 & 18.9 & 5.7 & $52.8 \%$ agree \\
\hline \begin{tabular}{|l|} 
ITO reduces organizational costs \\
\end{tabular} & 7.5 & 5.7 & 22.6 & 35.8 & 28.3 & $86.7 \%$ disagree \\
\hline
\end{tabular}


It must be noted that in the comment column in Table 2, a Neutral response has been relegated to negative side that includes Disagree and Strongly Disagree.

Table 3: IT Outsourcing Risks

\begin{tabular}{|l|c|c|c|c|c|c|}
\hline & No Risk & Low Risk & Medium Risk & High Risk & Very High Risk & Comment \\
\hline ITO brings loss of control to IT resources & 5.7 & 7.5 & 43.4 & 22.6 & 20.8 & Majority agree \\
\hline There a risk of hidden costs in the IT outsourcing contract & 1.9 & 5.7 & 20.8 & 43.4 & 28.3 & Majority agree \\
\hline ITO risks having less people being employed & 1.9 & 9.4 & 28.3 & 28.3 & 32.1 & Majority agree \\
\hline ITO reduces employee moral & 3.8 & 11.3 & 24.5 & 34.0 & 26.4 & Majority agree \\
\hline Vendor reputation is at risk & 1.9 & 17.0 & 26.4 & 32.1 & 22.6 & Majority agree \\
\hline
\end{tabular}

In terms of the risk profile of ITO, the study supports the proposition that ITO is a risk process. This is a qualified statement especially when one considers the respondents' opinion on loss of control, hidden costs, increasing unemployment, demoralizing staff and increasing vendor's bad image.

\section{Results Discussion and Conclusions}

This section presents a summary of the findings of the study as deduced from Table 2 and Table 3 above.

Proposition A:

Participants are knowledgeable of ITO purpose and its processes.

The results and analysis signify that most of IT staff is conversant with the concept of IT outsourcing. However, the research shows that there is neither an adopted framework nor an outsourcing structure for ITO being followed by the NWPG. Furthermore, there is no clear ITO strategy that has been adopted by the NWPG. As stated by Remenyi et al. (2007), there should be a methodology and approach, including tools, to measure critical success factors. According to Benvenuto and Brand (2005), a clear sound planning process enables key objectives to be identified, documented and addressed proactively. With this in mind, Proposition A can be addressed as follows:

While employees of the NWPG IT Directorate understand the ITO concept, they however do not have a sound knowledge of the processes, procedures and the importance of ITO.

The results reveal some concerns regarding the IT outsourcing by the NWPG. These concerns include lack of efficient and open communication channels between NWPG IT staff and management regarding outsourcing and no outsourcing plan with details regarding the transfer of assets, people, information, knowledge, hardware and software. According to Willcocks et al (2011), what matters most is how the strategy is planned, implemented and managed.

Proposition B:

ITO exposes the organization to more and better facilities and resources that increase its competitive advantage or variety superiority

The results reveal many benefits regarding IT outsourcing such as access to the best technology, improved performance and access to skilled, experienced and well-trained professionals. As stated by Gonzalez et al. (2009), IT outsourcing affords organisations to be on par with technology developments, effectively operating and managing their information technology infrastructure.

In addressing Proposition $B$, it is noted that:

There is a general feeling that ITO drivers do support the need for outsourcing the IT function in the department. The proposition is therefore supported.

The research also shows that IT functions most likely to be outsourced are the networking services, application development and maintenance and the mainframe applications.

Proposition C:

ITO does not expose the organization to operational risk.

IT outsourcing is not always smooth sailing. There are many risks that are associated with IT outsourcing. These risks include hidden costs in the contract, fewer jobs created, lower morale of employees and vendor reputation. The results in Table 3 do not support this proposition and therefore it is stated that:

ITO exposes the organization to risk.

This should however be read in conjunction with reflections from the participants "knowledge of ITO issues. One can safely argue that the lack of ITO process knowledge has impacted in some way on the respondents' view of ITO risk. Remember that from Table 2 above, participants indicated that they do not understand the concept of ITO. Based on 
these findings, NWPG is encouraged to:

- Adopt an outsourcing plan that will guide the outsourcing process.

- Establish a clear understanding of its requirements, perform due diligence as well as carry out risk assessment.

- Develop efficient and open communication channels between staff and management.

These recommendations can also be supplemented with some best practices that have been established elsewhere but have not been investigated in this study.

\section{References}

Arshad, N.H., May-Lin, Y. \& Mohamed, A. (2007). ICT Outsourcing: Inherent Risks, Issues and Challenges, 4(8), [Online], [Retrieved August 2007]. Available: http://www.wseas.us/e- library/transactions/economics/2007/24-107.pdf

Benvenuto, N.A., \& Brand, D. (2005). Outsourcing - A Risk Management Perspective, Information System Control Journal, 5.

Brandas, C. (2010). Risks and Audit Objectives for IT Outsourcing, Faculty of Economics and Business Administration, West University of Timisoara, [Online], Retrieved August 22, 2012], Available : http://ssrn.com/abstrac

Cox, M., Roberts M., \& Walton, J. (2011). IT Outsourcing in the Public Sector: Experiences from Local Government. Electronic Journal Information Systems Evaluation, 149(2), 193-203.

Deloitte.Com, IT Outsourcing Risks and how to mitigate them. [Online], Available: http://deloitte.wsj.com/cio/2012/07/10/it-outsourcing-4serious-risks-and-ways-to-mitigate-them.

Dominguez, L.R. (2006). The Manager's Step by Step Guide to Outsourcing. New York, Boston: Mc-Graw-Hill Companies.

Gonzalez, R., Gasco, J. \& Llopis, J. (2009). Information Systems Outsourcing Reasons and Risks: An Empirical Study. International Journal of Human and Social Sciences, 4(3), 181-192.

Haag, S., Cummings, M., \& Phillips, A. (2007). Management Information Systems for the information Age. New York: McGraw-Hill/Irwin.

Jones, W.O. (2009). Outsourcing: The Enduring Mistakes. Journal of Applied Business and Economics. [Online], Available :http://www.na-businesspress.com/jabe/jonesweb.pdf

Kremic, T. \& Tukel, O.I. (2006). Assisting Public Organizations in their Outsourcing Endeavours: A Decision Support Model. International Journal of Integrated Supply Management, 2(4), 383-406.

Mabe, L.L. (2010). North West Budget Vote 7 Speech. North West Provincial Legislature. [Online], [Retrieved March 25, 2012], Available: http://www.info.gov.za/speech.

Matthews, A.R. (2007). ITIL v3 and Outsourcing. How ITIL v3 can facilitate Outsourcing initiatives. Quint Wellington Redwood B.V. [Online], Available at: www.quintgroup.com

McMillan, L.L.P \& Shukla, R. (2010). The benefits and risks of outsourcing, Association of corporate Counsel [Online], Available: http://www.lexology.com/library/detail.aspx?

SITA. (2008). State Information Technology Agency Act, 1998: Act No. 88, 1998 .[Online], Available:http://www.sita.co.za

Remenyi, D., Bannister, F. \& Money, A. (2007). The Effective Measurement and Management of ICT Costs and Benefits, 3rd ed., Elsevier Ltd.

Rasool, F. (2011). SITA Contractors to Strike Arzana, IT Web, IT in Government Editor. Johannesburg, 22 Jul 2011, [Online], Available: http://www.itweb.co.za/index.php?

Smuts, H., Kotzé, P., Van der Merwe, A., \& Loock, M. (2010). Information Systems Outsourcing Issues in the Communication

Technology Sector. Proceedings of the IADIS International Conference Information Systems 2010, Porto, Portugal, ISBN: 978-972-893909-0, 18-20 March 2010, 145-155.

Struwig. F.W \& Stead, G.B. (2011). Planning, Designing and Reporting Research. Maskew Miller Longman Ltd: Pearson Education South Africa.

Sun. J. (2011). How much would you pay to have your shoelaces tied? [Online], Available: http://itnews@itweb.co.za

Willcocks, L.P., Cullen, S., \& Craig A. (2011). The Outsourcing Enterprise. Palgrave: Macmillan. 